\title{
Effect of Intra- and Postoperative Fluid and Blood Volume on Postoperative Pulmonary Edema in Patients With Intraoperative Massive Bleeding: Multi-Center Cohort Study Using Time Varying Analysis
}

\author{
Young Suk Kwon \\ Hallym University College of Medicine \\ Jun Woo Choi \\ Chuncheon Sacred Heart Hospital \\ Hanna Lee \\ Chuncheon sacred heart hospital \\ Jong Ho Kim \\ Chouncheon Sacred Heart Hospital \\ Ji Su Jang \\ Chuncheon Sacred Heart Hospital

\section{Sung Mi Hwang} \\ Chuncheon Sacred Heart Hospital \\ Ji Young Hong \\ Chuncheon Sacred Heart Hospital
}

\section{Go Eun Yang}

Kangwon National University Hospital

Youngmi Kim

Hallym University

Jae Jun Lee ( $\square$ iloveu59@hallym.or.kr)

Chuncheon Sacred Heart Hospital https://orcid.org/0000-0002-5418-500X

Research article

Keywords: intraoperative massive bleeding, postoperative pulmonary edema, volume management, time varying hazard analysis

Posted Date: November 10th, 2020

DOI: https://doi.org/10.21203/rs.3.rs-102629/v1 
License: (c) (i) This work is licensed under a Creative Commons Attribution 4.0 International License. Read Full License 


\section{Abstract}

\section{Background}

In patients with massive bleeding during surgery, the effect of intra- and postoperative fluid and blood volume on postoperative pulmonary edema is uncertain. The aim of this study is evaluating the occurrence risk relationship through time-varying analysis between postoperative pulmonary edema and intra- and postoperatively administered volume of fluid and blood in patients with intraoperative massive bleeding.

\section{Methods}

This study is a retrospective cohort study and data was obtained from the clinical data warehouse at Hallym University Medical Center, a multi-institutional data registry of 5 hospitals of Hallym University. Patients with intraoperative massive bleeding ( $\geq 40 \%$ of average blood volume) and who underwent a non-cardiac surgery at 5 hospitals between January 1, 2010, and December 31, 2019 were enrolled the study. The primary outcome was postoperative pulmonary edema occurrence within 72 hours after surgery. Secondary outcomes were postoperative pulmonary edema with hypoxemia.

\section{Results}

In total, 2090 patients were included in the postoperative pulmonary edema analysis, and 300 patients developed pulmonary edema within 72 hours after surgery. The postoperative pulmonary edema hypoxemia analysis with hypoxia included 1660 patients; pulmonary edema with hypoxemia occurred in 161 patients. The increase in the amount of red blood cells/average blood volume/hour after surgery increased the risk of developing pulmonary edema after surgery (hazard ratio: $1.03,95 \%$ confidence interval [1.01-1.05], $\mathrm{P}=0.013$ ) and the risk of developing pulmonary edema with hypoxemia (hazard ratio: $1.04,95 \%$ confidence interval [1.01-1.07], $P=0.024)$.

\section{Conclusion}

In this study, an increase in the transfusion of red blood cells per hour after surgery increased the risk of developing pulmonary edema after surgery. This increase can be considered a risk factor for the incidence of pulmonary edema.

\section{Background}

Massive bleeding during surgery is a life-threatening event in the operating room and increases postoperative mortality.[1] When massive bleeding occurs during surgery, When massive bleeding occurs during surgery, a relatively large volume of fluid and blood is administered to compensate for the loss thereof, which could result in fluid overload. Fluid overload with high hydrostatic pressures resulting in left ventricular dysfunction would be the most common consequence of postoperative pulmonary edema. [2] Massive transfusion after massive bleeding may cause coagulopathy,[3] acid-base abnormalities,[4] 
hypothermia,[5] and transfusion-related acute lung injury.[6] These complications of massive transfusions may also be related to pulmonary edema.[7-10]

Intraoperative fluid therapy is complex because it generally includes replacement of the maintenance requirement, existing fluid deficits, and surgical wound losses including blood loss. Moreover, it is challenging to evaluate accurately the bleeding volume during surgery[11] and to perform transfusion safely.[12] After surgery, more fluid and blood may be needed due to postoperative bleeding, or complications due to intraoperative massive transfusion. Therefore, administration of fluid and transfusion therapy are more difficult after surgery. Moreover, currently, there is no clinical approach to safely administer fluid and blood. Surgeons and anesthesiologists perform fluid and transfusion therapy based on a combination of various clinical approximations. Perioperative fluid and transfusion management in massive bleeding during surgery continues to be a daily challenge to surgeons and anesthesiologists.

In this study, we aimed to determine the intra- and postoperative fluid and transfusion volume, which can be measured accurately. We also investigated the effect of the volume of fluid and blood administered during and after surgery on the development of postoperative pulmonary edema in patients with intraoperative massive bleeding using a time-varying hazards analysis.

\section{Materials And Methods}

\section{Data collection}

This retrospective cohort study was approved by the Clinical Research Ethics Committee of Chuncheon Sacred Heart Hospital, Hallym University. All data were obtained from the clinical data warehouse of 5 hospitals at Hallym University Medical Center, between January 1, 2010, and December 31, 2019. The clinical data warehouse is a database of medical records, prescriptions, and test results; the data can be searched in multiple ways to identify patients, i.e., by prescription, examination type, and diagnosis. The time and results of patient tests can be extracted, in addition to their drug administration status, transfusion status, and overall medical records, in an unstructured text format.

\section{Patients}

Bleeding is divided into four classes according to the American College of Surgeons' Advanced Trauma Life Support classification.[13] Class 4 corresponds to a loss of $>40 \%$ of the circulating blood volume. In this study, estimated blood loss $>40 \%$ of average blood volume (males: body weight [kg] $\otimes 75 \mathrm{ml}$; female: body weight [kg] $\otimes 65 \mathrm{ml}$ )[11] during surgery was defined as massive bleeding; patients with massive bleeding during surgery were included. Patients meeting specific criteria were excluded, which include:

- Patients $<18$ years of age;

- Patients undergoing cardiac surgery;

- Patients who underwent a previous surgery within 7 days before the present surgery. 
- Patients with pulmonary edema or hypoxemia $\left(\mathrm{PaO}_{2} / \mathrm{FiO}_{2} \leq 300\right)$ before surgery

Although no arterial blood gas ( $A B G$ ) analysis was found, patients who did not receive oxygen therapy due to no respiratory symptoms after surgery and did not have pulmonary edema findings on chest X-ray were considered to have absence of hypoxemia.

\section{Primary and Secondary Outcomes}

The primary outcome was the presence of pulmonary edema on postoperative chest X-ray. chest X-rays were used for consistency in the diagnosis of pulmonary edema, and all chest X-rays were evaluated by radiologists. The secondary outcome was pulmonary edema with hypoxemia after surgery. $\mathrm{PaO} 2 / \mathrm{FiO} 2 \leq$ 300 was defined as hypoxemia. The results with the least time interval between chest X-ray and ABG analysis were used. Patients who had no pulmonary edema on chest X-ray and did not receive oxygen therapy due to no respiratory symptoms were considered to have absence of pulmonary edema. Since postoperative pulmonary edema could occur up to 3 days after the operation, [12] it was confirmed whether postoperative pulmonary edema occurred until 72 hours after surgery.

\section{Major variables}

The major variables to be evaluated in this study were divided into intra- and postoperative variables. Intraoperative variables include the total amount of fluid administered during surgery, the amount of fluid administered per hour, the total amount of red blood cells administered, the amount of red blood cells administered per hour, the total amount of frozen fresh plasma (FFP) administered and the amount of FFP administered per hour.

Postoperative variables include the total amount of fluid administered after surgery, the amount of fluid administered per hour, the total amount of red blood cells administered, the amount of red blood cells administered per hour, the total amount of FFP administered and the amount of FFP administered per hour. All postoperative major variables were used as time-varying variables. The amount of fluid and blood administered after surgery were measured based on the ABG analysis test time or the chest X-ray test time. In the analysis of pulmonary edema with hypoxemia, when both ABG analysis and chest X-ray were tested, the dose was measured based on the ABG analysis test time, and when there were no respiratory symptoms and only the chest $\mathrm{X}$-ray test was performed, the amount was measured based on the chest X-ray test time. The administered fluid and blood volume were expressed as a percentage of the patient's average blood volume. Each patient had 1-3 time-varying variables and observation periods depending upon the number of measurements according to the test frequency. The first observation period was from the end of anesthesia to the time of the first test; the second observation period was from the time of the first test to the second test, and the third observation period was from the second test to the third test.

\section{Other variables}


Many other covariates were used to adjust for any residual confounding or indication bias. Demographic variables included old age ( $\geq 70$ years), male sex, and obesity (body mass index $\geq 30$ ). Preoperative variables included emergency, American Society of Anesthesiologists physical status $>2$, smoking, brain trauma, multiple fractures, hyponatremia ( $<135 \mathrm{mmol} / \mathrm{L})$, hypoalbuminemia $(<3.5 \mathrm{~g} / \mathrm{dL})$ and glomerular filtration rate. Intraoperative variables included general anesthesia, anesthesia time, kinds of surgery (acute abdomen, aorta, brain, spine, thoracic), massive transfusion (packed red blood cells more than 4 pint/hour),[14] urine output $<0.5 \mathrm{ml} / \mathrm{kg} /$ hour, continuous inotropes use and estimated blood loss. Postoperative variables included patient-controlled analgesia and whether or not creatinine increased by 0.3 compared to that before surgery.[15]

\section{Statistical Analysis}

Continuous variables were expressed as median and interquartile ranges due to skewness. Categorical variables were summarized as frequency and percentages. Continuous data were analyzed using the Mann-Whitney test, to compare patients with postoperative pulmonary edema and patients without postoperative pulmonary edema. Categorical data were analyzed using the chi-square test. Cox's timevarying hazards model was used to analyze the hazard ratio of the major variables for the occurrence of postoperative pulmonary edema within 72 hours after surgery. Time-varying covariance occurs when the covariate changes over time during the tracking period. These variables can be analyzed with a timevarying Cox regression model to estimate their effect on event occurrence time. [16] All reported P-values were two-sided; a P-value < 0.05 was considered to indicate statistical significance. SPSS (version 24.0; IBM Corp., Armonk, NY, USA) was used for all statistical analyses except for time-varying Cox regression analysis. Anaconda (Python version 3.7, https://www.anaconda.com; Anaconda Inc., Austin, TX) and Lifelines (version 0.24.15; https://github.com/CamDavidsonPilon/lifelines/blob/master/docs/index.rst) were used for time-varying Cox regression analysis.

\section{Results}

\section{Study population}

Between January 1, 2010, and December 31, 2019, there were a total of 2161 patients who had a bleeding amount $>40 \%$ of average blood volume during surgery, and hence these patients were included. Seventyone patients were excluded because of missing data, and 2090 patients without missing data were included in the primary outcome analysis. There was one follow-up period in 638 patients, two follow-up periods in 407 patients, and three follow-up periods in 1045 patients. Furthermore, 300 patients had pulmonary edema findings on chest X-ray; the time-fixed variables and time-varying variables are summarized in Table 1. In the analysis of pulmonary edema with hypoxemia, 430 patients without data of $\mathrm{PO}_{2}$ or $\mathrm{FiO}_{2}$ were excluded, and 1630 patients were included. Moreover, 161 patients had postoperative pulmonary edema with hypoxemia; the time-fixed variables and time-varying variables are summarized in Table 2. There was one follow-up period in 848 patients, two follow-up periods in 499 patients, and three follow-up periods in 313 patients. 


\section{Follow-up period}

The observation period was divided into 6 types according to the start time and the end time of follow-up observation, and variables and observation results were expressed in each observation period (Tables 1 [page 19] and 2 [page 23]). There was one observation result during the follow-up period, and depending on the

number of observations, patients were included in several periods. The number of patients included in each period and the number of patients with outcomes are listed in Tables 1 (page 19) and 2 , respectively. The median of the time interval between the chest X-ray and ABG analysis was 2.4 (interquartile range, 1.1-5.6) hours.

Hazard ratio of postoperative pulmonary edema with and without hypoxemia postoperatively within 72 hours

The unadjusted and adjusted hazard ratio for major variables and kidney-related variables (preoperative glomerular filtration rate, intraoperative urine output $\leq 0.5 \mathrm{ml} / \mathrm{kg} / \mathrm{hour}$, postoperative creatinine increasing) of pulmonary edema with and without hypoxemia postoperatively within 72 hours are shown in Figure 1 and Figure 2, respectively. Postoperatively administered total fluid (adjusted hazard ratio, 1.00; 95\% confidence interval, 1.00-1.00: $\mathrm{P}<0.001$ ) and postoperative red blood cells per hour (adjusted hazard ratio , 1.03; 95\% confidence interval, 1.01-1.05: $P=0.013$ ) showed significant difference in hazard ratio in the unadjusted and adjusted analyses of postoperative pulmonary edema. Postoperative administered total fluid (adjusted hazard ratio , 1.00; 95\% confidence interval, 1.00-1.00: $P=0.005$ ) and postoperative red blood cells per hour (adjusted hazard ratio , 1.04; 95\% confidence interval, 1.01-1.07: P $=0.024$ ) showed significant differences in hazard ratio in the unadjusted and adjusted analyses of postoperative pulmonary edema with hypoxemia. Intraoperative FFP per hour had a significant difference in hazard ratios only in postoperative pulmonary edema (adjusted hazard ratio, 1.03; $95 \%$ confidence interval, 1.00-1.06; $P<0.042$ ). The other major variables did not show significant results. The data of adjusted hazard ratio of variables that are not shown in Figures 1 and 2 are shown in Table 3 (page 27) and 4 (page 28).

\section{Discussion}

Through time-varying Cox regression, it was shown that the total amount of fluid administered after surgery and the amount of red blood cells administered per hour were associated with an increased risk of postoperative pulmonary edema with hypoxemia as well as postoperative pulmonary edema. However, the hazard ratio for the occurrence of postoperative pulmonary edema in the total amount of fluid administered after surgery was so small that the clinical significance was not significant.

Our findings show that in patients with massive intraoperative bleeding, the amount of red blood cells administered per hour after surgery increases the risk of developing postoperative pulmonary edema. Exacerbation of pre-existing anemia, bleeding during surgery and repeated laboratory blood test are 
common causes of postoperative anemia.[17-19] If the anemia is severe or difficult to correct, more red blood cell transfusions may be required. Anemia and pulmonary edema are interrelated.[20-22] Existing severe anemia can often be associated with salt and water retention,[23-25] and hormonal and metabolic changes due to low hemoglobin levels can also cause direct myocardial toxicity, myocardial hypertrophy, and increase salt and water retention.[20,26] Heart failure can lead to anemia through a variety of mechanisms such as iron deficiency, inflammation, low erythropoietin level, medication, hemodilution, and medullar dysfunction .[27]

The essential principle of fluid balance in the body is that the amount of water lost should be equal to the amount of fluid received.[28] However, increased weight is common in patients undergoing surgery; this is typically a result of a positive fluid balance.[29, 30] Cooperman et al. reported $2.1 \pm 0.4 \mathrm{~L}$ of bleeding and $3.7 \pm 0.6 \mathrm{~L}$ of replacement in postoperative pulmonary edema patients; fluid overload was exhibited by half of their patients.[31] Arieff et al. reported that if fluid retention exceeded $67 \mathrm{ml} / \mathrm{kg} / \mathrm{day}$, postoperative pulmonary edema could occur.[32] Holte et al. reported that administration of $40 \mathrm{ml} / \mathrm{kg}$ infusion of lactated Ringer's solution for 3 hours caused a reduction in pulmonary function.[33] Massive bleeding also causes fluid imbalance, and massive volumes of fluid and blood should be administered rapidly in such cases. Massive administration of blood products may cause transfusion-associated circulatory overload,[14] and fluid overload can in turn cause postoperative pulmonary edema.[2, 31, 32, 34]

In this study, there were no variables related to both the occurrence risk of postoperative pulmonary edema and postoperative pulmonary edema with hypoxemia in the amounts of fluid and blood administered during surgery. Perioperative fluids and blood transfusions can cause hypothermia,[35-37] which can lead to impaired coagulation and acidosis,[38, 39] as well as pulmonary edema.[9] Administered fluid and blood following bleeding can occur due to dilutional coagulopathy, platelet dysfunction, fibrinolysis, or hypofibrinogenemia. And they are prone to occur when massive bleeding and large amounts of fluids and blood are administered as compensation for bleeding. $[3,40,41]$ Coagulation disorders such as the above are present in many patients after surgery and make the patient's bleeding worse.[42, 43] Exacerbation of bleeding and resulting anemia increases the need for blood transfusions after surgery.[44] Increased exposure to blood transfusions may pose a risk of developing transfusionrelated acute lung injury and transfusion-associated circulatory overload.[45, 46] Acidosis and hypocalcemia caused by increased blood transfusions can be predisposing conditions that affect heart contractility and cause pulmonary edema.[47-49] However, correctable abnormalities may not last long, because during surgery, close monitoring is performed to check for abnormalities such as anemia,[50] volume status,[51] body temperature, electrolyte and coagulation abnormalities that may affect the occurrence of postoperative pulmonary edema, and immediate correction is attempted.[35-39, 52] Because pulmonary edema is not visible on chest X-ray until the amount of lung fluid increases by $30 \%$ relative to normal volume,[53] if there is no sudden increase of lung fluid due to close monitoring during surgery, postoperative pulmonary edema may not be visible. However, in patients with massive bleeding, if sufficient resuscitation is not achieved during surgery, organ failure may occur after surgery,[54] which may affect the development of pulmonary edema after surgery.[55-57] Even after surgery, it is recommended to frequently monitor the patient's volume condition using readily available clinical 
parameters such as vital signs, urine output, lung auscultation, weight change, and net fluid retention calculations $[58,59]$ but even doctors do not seem to monitor closely until lung edema is diagnosed.[32]

In this study, an increase in FFP/hour during surgery increased the risk of postoperative pulmonary edema. While FFP is used in cases of clotting factor deficiency to prevent clotting disorders, the use of FFP puts the patients at risk for transfusion-related acute lung injury[6] and can cause circulatory overload in patients with kidney or cardiopulmonary failure.[60] The fact that an increase in FFP/hour during surgery is not associated with an increased risk of postoperative pulmonary edema with hypoxemia is a matter for further study.

Kidney function may also be closely related to the development of pulmonary edema.[57, 61, 62] Our study evaluated renal function with preoperative glomerular filtration rate, intraoperative oliguria, and increased postoperative creatinine, and it was found that increased postoperative creatinine increased the risk of postoperative pulmonary edema. The kidneys play an important role in many homeostasis mechanisms in the body and communicate with the lungs by regulating acid-base balance, increasing oxygen-carrying capacity through red blood cell production, and regulating blood pressure through the renin-angiotensin-aldosterone axis. However, as the acute kidney injury (AKI) progresses, these processes can become impaired.[57] If there is anemia, shock, or hemodilution during surgery, the risk of developing AKI increases after the surgery, $[63,64]$ but these are more likely to occur in patients with massive bleeding during surgery.[65-67] During anesthesia, because the blood vessels expand, fluid retention may occur,[68] and since the operation time is shorter than the follow-up period after surgery, it may be difficult to see kidney damage due to oliguria during surgery.[69]

In this study, time-varying Cox regression was used to evaluate the hazard ratio. Time-varying covariance occurs when a given covariate changes over time during the follow-up period, a phenomenon commonly seen in clinical studies.[16, 70] In patients with massive bleeding during surgery, the patient's condition after surgery may change in various ways, and according to the change in condition, several tests are performed and the results are measured. In addition, the fluid and transfusion volume will be modified accordingly. In such cases where there are many changes after surgery, a time-varying model may be appropriate.

\section{Limitations}

A strength of this study was that a large number of patients with massive bleeding during surgery were included. However, because it is difficult to perform a randomized controlled trial of massive bleeding patients, this study used a retrospective design, which is subject to bias. pulmonary edema is either cardiogenic or non-cardiogenic, but we could not stratify patients based on pulmonary edema type. Although the different types of pulmonary edema have different causes, it is difficult to distinguish them due to their similar clinical features. In addition, the causes can be complex in critically ill patients[55] and both types of postoperative pulmonary edema can occur in patients with massive bleeding during surgery.[34, 45, 46] The gold standard for determining the cause of acute pulmonary edema is the insertion of a pulmonary artery catheter but, this is not routinely performed.[71] Instead, in this study, we 
assessed pulmonary edema using a much less invasive method, the chest $\mathrm{X}$-ray, and considered certain radiographic features that may help determine the cause of the edema.[55, 72] In addition, hypoxemia was considered and analyzed to evaluate the objectivity and severity of pulmonary edema symptoms. Finally, this study did not include data on the output of body fluids after surgery. Except for some serious patients admitted to the intensive care unit, no data on postoperative fluid output were available for the follow-up period. Instead, we evaluated the assessment of kidney function related to urinary excretion with changes in creatinine levels.

\section{Conclusions}

This study provides information that the incidence of postoperative pulmonary edema is high in patients with massive bleeding during surgery, and an increase in the amount of transfusion of red blood cells after surgery present in the perioperative fluid and blood may be a risk factor for the incidence of pulmonary edema and thus expands the results of previous studies. In patients with massive bleeding during surgery, close monitoring and rapid correction of factors that cause postoperative anemia and bleeding may be more important. Further prospective population-based studies are needed to explain the mechanism underlying the association between postoperative red blood cells transfusion and the risk of developing postoperative pulmonary edema in patients with intraoperative massive bleeding.

\section{Abbreviations}

$A B G$ arterial blood gas

FFP fresh frozen plasma

AKI acute kidney injury

\section{Declarations}

\section{Ethics approval and consent to participate}

This study was approved by the Clinical Research Ethics Committee of Chuncheon Sacred Heart Hospital, Hallym University. (IRB No. 2019-01-012)

\section{Consent for publication}

Not applicable

\section{Availability of data and materials}

The datasets used and/or analyzed during the current study are available from the corresponding author on reasonable request. 


\section{Competing interests}

The authors declare that they have no competing interests

\section{Funding}

The design of this study and collection, analysis, and interpretation of data was supported by the Bio \& Medical Technology Development Program of the National Research Foundation (NRF) funded by the Korean government (MSIT) (NRF-2017M3A9E8049714, 2017M3A9E8033205, 2019M3A9E8020536), South Korea

\section{Authors' contributions}

Young suk Kwon contributed to this work as first authors.

Jae Jun Lee contributed to this work as corresponding author and guarantor.

Study concept and design: Yang, JW Choi, Kwon.

Acquisition of data: Hwang, Jang, JJ Lee, JH Kim, Hong, Yang, YM Kim.

Analysis and interpretation of data: Kwon, Kim

Drafting of the manuscript: Kwon, JJ Lee, Jang, Hwang, JW Choi.

Study supervision: YM Kim, JJ Lee, Kwon, Jang

Revising paper: all authors

\section{Acknowledgements}

Not applicable

\section{References}

1. Irita K: Risk and crisis management in intraoperative hemorrhage: Human factors in hemorrhagic critical events. Korean J Anesthesio/ 2011, 60(3):151-160.

2. Lowell JA, Schifferdecker C, Driscoll DF, Benotti PN, Bistrian BR: Postoperative fluid overload: not a benign problem. Crit Care Med 1990, 18(7):728-733.

3. Levy JH: Massive Transfusion Coagulopathy. Seminars in Hematology 2006, 43:S59-S63.

4. Sihler KC, Napolitano LM: Complications of massive transfusion. Chest 2010, 137(1):209-220.

5. Reynolds BR, Forsythe RM, Harbrecht BG, Cuschieri J, Minei JP, Maier RV, Moore EE, Billiar TR, Peitzman $A B$, Sperry $\mathrm{JL}$ et al: Hypothermia in massive transfusion: Have we been paying enough attention to it? Journal of Trauma and Acute Care Surgery 2012, 73(2):486-491. 
6. Toy P, Popovsky MA, Abraham E, Ambruso DR, Holness LG, Kopko PM, McFarland JG, Nathens AB, Silliman CC, Stroncek D et al: Transfusion-related acute lung injury: Definition and review. Critical Care Medicine 2005, 33(4):721-726.

7. Vercellini P, Rossi R, Pagnoni B, Fedele L: Hypervolemic pulmonary edema and severe coagulopathy after intrauterine dextran instillation. Obstetrics and gynecology 1992, 79(5 (Pt 2)):838-839.

8. Vaisrul S: Acid-base imbalance in pulmonary edema. JAMA 1971, 216(8):1337-1337.

9. Su Y-J: Hypothermic lung edema after accidental hypothermia with out of hospital cardiac arrest. Heart, lung and vessels 2015, 7(4):328.

10. Gajic O, Gropper MA, Hubmayr RD: Pulmonary edema after transfusion: How to differentiate transfusion-associated circulatory overload from transfusion-related acute lung injury. Critical Care Medicine 2006, 34(5):S109-S113.

11. Butterworth JF, Mackey DC, Wasnick JD: Clinical Anesthesiology, 6th edn. New York, NY: The McGraw-Hill Education; 2018.

12. Arieff Al: Fatal Postoperative Pulmonary Edema: Pathogenesis and Literature Review. Chest 1999, 115(5):1371-1377.

13. Chapleau W, Al-Khatib J, Haskin D, LeBlanc P, Cárdenas G, Borum S, Torres N, al Ghanimi O, Al-Harthy A, Ali JJTJoT et al: Advanced trauma life support (ATLS®): the ninth edition. 2013, 74(5):1363-1366.

14. Patil V, Shetmahajan M: Massive transfusion and massive transfusion protocol. Indian J Anaesth 2014, 58(5):590-595.

15. Mehta RL, Kellum JA, Shah SV, Molitoris BA, Ronco C, Warnock DG, Levin A, the Acute Kidney Injury $\mathrm{N}$ : Acute Kidney Injury Network: report of an initiative to improve outcomes in acute kidney injury. Critical Care 2007, 11(2):R31.

16. Zhang Z, Reinikainen J, Adeleke KA, Pieterse ME, Groothuis-Oudshoorn CGM: Time-varying covariates and coefficients in Cox regression models. Ann Trans/ Med 2018, 6(7):121-121.

17. Warner MA, Shore-Lesserson L, Shander A, Patel SY, Perelman SI, Guinn NR: Perioperative anemia: prevention, diagnosis, and management throughout the spectrum of perioperative care. Anesthesia \& Analgesia 2020, 130(5):1364-1380.

18. Muñoz M, Acheson A, Bisbe E, Butcher A, Gómez-Ramírez S, Khalafallah A, Kehlet H, Kietaibl S, Liumbruno G, Meybohm P: An international consensus statement on the management of postoperative anaemia after major surgical procedures. Anaesthesia 2018, 73(11):1418-1431.

19. Koch CG, Li L, Sun Z, Hixson ED, Tang AS, Phillips SC, Blackstone EH, Henderson JM: From bad to worse: anemia on admission and hospital-acquired anemia. Journal of patient safety 2017, 13(4):211-216.

20. Anand IS, Chandrashekhar Y, Ferrari R, Poole-Wilson PA, Harris PC: Pathogenesis of oedema in chronic severe anaemia: studies of body water and sodium, renal function, haemodynamic variables, and plasma hormones. Br Heart J 1993, 70(4):357-362. 
21. Rovellini A, Graziadei G, Folli C, Brambilla AM, Cosentini R, Canetta C, Monzani V: Causes and correlates of anemia in $\mathbf{2 0 0}$ patients with acute cardiogenic pulmonary edema. European journal of internal medicine 2012, 23(8):733-737.

22. Somers K: Acute reversible heart failure in severe iron-deficiency anemia associated with hookworm infestation in Uganda Africans. Circulation 1959, 19(5):672-675.

23. Varat MA, Adolph RJ, Fowler NO: Cardiovascular effects of anemia. American heart journal 1972 , 83(3):415-426.

24. GRAETTINGER JS, PARSONS RL, CAMPBELL JA: A correlation of clinical and hemodynamic studies in patients with mild and severe anemia with and without congestive failure. Annals of internal medicine 1963, 58(4):617-626.

25. Sanghvi L, Sharma V, Mansharamani G: Mechanism of oedema in chronic severe anaemia. Br Heart J 1963, 25(1):89.

26. Schrier RW, Abraham WT: Hormones and hemodynamics in heart failure. New England Journal of Medicine 1999, 341(8):577-585.

27. Sîrbu O, Floria M, Dascalita P, Stoica A, Adascalitei P, Sorodoc V, Sorodoc L: Anemia in heart failurefrom guidelines to controversies and challenges. Anatolian journal of cardiology 2018, 20(1):52.

28. AC G, JE H: Textbook of Medical Physiology, 11th edn. Philadelphia: Elsevier; 2006.

29. Holte K, Sharrock NE, Kehlet H: Pathophysiology and clinical implications of perioperative fluid excess. Br J Anaesth 2002, 89(4):622-632.

30. Brandstrup B, Tonnesen H, Beier-Holgersen R, Hjortso E, Ording H, Lindorff-Larsen K, Rasmussen MS, Lanng C, Wallin L, Iversen LH et al: Effects of intravenous fluid restriction on postoperative complications: comparison of two perioperative fluid regimens: a randomized assessor-blinded multicenter trial. Ann Surg 2003, 238(5):641-648.

31. Cooperman LH, Price HLJAos: Pulmonary edema in the operative and postoperative period: a review of 40 cases. $1970,172(5): 883$.

32. Arieff Al: Fatal postoperative pulmonary edema: pathogenesis and literature review. Chest 1999, 115(5):1371-1377.

33. Holte $\mathrm{K}$, Jensen $\mathrm{P}$, Kehlet $\mathrm{H}$ : Physiologic effects of intravenous fluid administration in healthy volunteers. Anesth Analg 2003, 96(5):1504-1509, table of contents.

34. Singh B, Kulshrestha AJAom, research hs: Diagnosis, prevention and management of postoperative pulmonary edema. Ann Med Health Sci Res 2012, 2(2):180-185.

35. Díaz M, Becker DE: Thermoregulation: physiological and clinical considerations during sedation and general anesthesia. Anesth Prog 2010, 57(1):25-34.

36. Reynolds BR, Forsythe RM, Harbrecht BG, Cuschieri J, Minei JP, Maier RV, Moore EE, Billiar EE, Peitzman AB, Sperry JL: Hypothermia in massive transfusion: have we been paying enough attention to it? The journal of trauma and acute care surgery 2012, 73(2):486-491. 
37. Oshvandi K, Shiri FH, Fazel MR, Safari M, Ravari A: The effect of pre-warmed intravenous fluids on prevention of intraoperative hypothermia in cesarean section. Iran J Nurs Midwifery Res 2014, 19(1):64-69.

38. Martini WZ: Coagulopathy by hypothermia and acidosis: mechanisms of thrombin generation and fibrinogen availability. The Journal of trauma 2009, 67(1):202-208; discussion 208-209.

39. Wolberg AS, Meng ZH, Monroe DM, 3rd, Hoffman M: A systematic evaluation of the effect of temperature on coagulation enzyme activity and platelet function. The Journal of trauma 2004, 56(6):1221-1228.

40. Ghadimi K, Levy JH, Welsby IJ: Perioperative management of the bleeding patient. BJA: British Journal of Anaesthesia 2016, 117(suppl_3):iii18-iii30.

41. Meißner A, Schlenke P: Massive Bleeding and Massive Transfusion. Transfus Med Hemother 2012, 39(2):73-84.

42. van de Wiel A: Anemia in critically ill patients. European journal of internal medicine 2004, 15(8):481486.

43. Levi M, Opal SM: Coagulation abnormalities in critically ill patients. Crit Care 2006, 10(4):222-222.

44. Liumbruno GM, Bennardello F, Lattanzio A, Piccoli P, Rossetti G, Italian Society of Transfusion M, Immunohaematology Working P: Recommendations for the transfusion management of patients in the peri-operative period. III. The post-operative period. Blood Transfus 2011, 9(3):320-335.

45. Benson AB: Pulmonary complications of transfused blood components. Crit Care Nurs Clin North Am 2012, 24(3):403-418.

46. Roubinian N: TACO and TRALl: biology, risk factors, and prevention strategies. Hematology Am Soc Hematol Educ Program 2018, 2018(1):585-594.

47. Handy J, Soni N: Physiological effects of hyperchloraemia and acidosis. British journal of anaesthesia 2008, 101(2):141-150.

48. DiFrancesco NR, Gaffney TP, Lashley JL, Hickerson KA: Hypocalcemia and Massive Blood Transfusions: A Pilot Study in a Level I Trauma Center. Journal of trauma nursing : the official journal of the Society of Trauma Nurses 2019, 26(4):186-192.

49. Rosenkranz S, Gibbs JSR, Wachter R, De Marco T, Vonk-Noordegraaf A, Vachiéry J-L: Left ventricular heart failure and pulmonary hypertension. Eur Heart J 2016, 37(12):942-954.

50. Barker SJ, Shander A, Ramsay MA: Continuous Noninvasive Hemoglobin Monitoring: A Measured Response to a Critical Review. Anesth Analg 2016, 122(2):565-572.

51. Endo Y, Tamura J, Ishizuka T, Itami T, Hanazono K, Miyoshi K, Sano T, Yamashita K, Muir WW: Stroke volume variation (SVV) and pulse pressure variation (PPV) as indicators of fluid responsiveness in sevoflurane anesthetized mechanically ventilated euvolemic dogs. J Vet Med Sci 2017, 79(8):14371445.

52. Checketts MR, Alladi R, Ferguson K, Gemmell L, Handy JM, Klein AA, Love NJ, Misra U, Morris C, Nathanson $\mathrm{MH}$ et al: Recommendations for standards of monitoring during anaesthesia and 
recovery 2015: Association of Anaesthetists of Great Britain and Ireland. Anaesthesia 2016, 71(1):8593.

53. Pistolesi M, Giuntini CJRCoNA: Assessment of extravascular lung water. 1978, 16(3):551-574.

54. Waxman K: Postoperative multiple organ failure. Critical care clinics 1987, 3(2):429-440.

55. Ware LB, Matthay MA: Acute Pulmonary Edema. 2005, 353(26):2788-2796.

56. Clark SB, Soos MP: Noncardiogenic Pulmonary Edema. In: StatPearls [Internet]. edn.: StatPearls Publishing; 2020.

57. Basu RK, Wheeler D: Effects of ischemic acute kidney injury on lung water balance: nephrogenic pulmonary edema? Pulmonary medicine 2011, 2011.

58. Shires GT, Canizaro PC, Lowry S: Fluid, electrolyte, and nutritional management of the surgical patient. Principles of surgery 1994, 6:61-80.

59. Darby J, Nelson P: Fluid, electrolyte, and acid-base balance in neurosurgical intensive care. Neurosurgical Intensive Care New York: McGraw-Hill 1993:133-162.

60. Liumbruno G, Bennardello F, Lattanzio A, Piccoli P, Rossetti G, Italian Society of Transfusion M, Immunohaematology Work G: Recommendations for the transfusion of plasma and platelets. Blood Transfus 2009, 7(2):132-150.

61. Faubel S: Pulmonary complications after acute kidney injury. Advances in chronic kidney disease 2008, 15(3):284-296.

62. Farha N, Munguti C: A Dramatic Presentation of Pulmonary Edema Due to Renal Failure. Kans J Med 2020, 13:56-57.

63. Park JT: Postoperative acute kidney injury. Korean J Anesthesio/ 2017, 70(3):258-266.

64. Han SS, Baek SH, Ahn SY, Chin HJ, Na KY, Chae DW, Kim S: Anemia Is a Risk Factor for Acute Kidney Injury and Long-Term Mortality in Critically III Patients. The Tohoku journal of experimental medicine 2015, 237(4):287-295.

65. Terceros-Almanza LJ, García-Fuentes C, Bermejo-Aznárez S, Prieto-Del Portillo IJ, Mudarra-Reche C, Sáez-de la Fuente I, Chico-Fernández M: Prediction of massive bleeding. Shock index and modified shock index. Medicina intensiva 2017, 41(9):532-538.

66. Alder L, Tambe A: Acute Anemia. In: StatPearls [Internet]. edn.: StatPearls Publishing; 2019.

67. Bolliger D, M.D., Görlinger K, M.D., Tanaka KA, M.D., M.Sc.: Pathophysiology and Treatment of Coagulopathy in Massive Hemorrhage and Hemodilution. Anesthesiology: The Journal of the American Society of Anesthesiologists 2010, 113(5):1205-1219.

68. Hahn RG, Lyons G: The half-life of infusion fluids: An educational review. Eur J Anaesthesio/2016, 33(7):475-482.

69. Hobson C, Ruchi R, Bihorac A: Perioperative Acute Kidney Injury: Risk Factors and Predictive Strategies. Critical care clinics 2017, 33(2):379-396.

70. Austin PC: Generating survival times to simulate Cox proportional hazards models with time-varying covariates. Statistics in Medicine 2012, 31(29):3946-3958. 
71. de la Ventilacio Mecanica SB, Miranda M: Kelly CR, Rabbani LE. Pulmonary-Artery Catheterization N Engl J Med 2013.

72. Milne EN, Pistolesi M, Miniati M, Giuntini C: The radiologic distinction of cardiogenic and noncardiogenic edema. American Journal of Roentgenology 1985, 144(5):879-894.

\section{Tables}

Table 1. Demographic characteristics and clinical data in analysis of postoperative pulmonary edema 
Variable

No

Postoperative

pulmonary

edema $(n=$

1790)

\section{Demographics}

\begin{tabular}{|llll}
\hline Old Age, No. (\%) & $496(27.7)$ & $108(36.0)$ & 0.003 \\
\hline Men, No. (\%) & $904(50.5)$ & $148(49.3)$ & 0.71 \\
\hline Obesity, No. (\%) & $68(3.8)$ & $11(3.7)$ & 0.91
\end{tabular}

Preoperative Clinical features

\begin{tabular}{llll}
\hline Emergency, No. (\%) & $647(36.1)$ & $148(49.3)$ & $<0.001$ \\
\hline $\begin{array}{l}\text { American Society of Anesthesiologists } \\
\text { physical status > 2, No. (\%) }\end{array}$ & $862(48.2)$ & $186(62.0)$ & $<0.001$ \\
\hline Tobacco use, No. (\%) & $415(23.2)$ & $62(20.7)$ & 0.346 \\
\hline Brain trauma, No. (\%) & $230(12.8)$ & $42(14.0)$ & 0.58 \\
\hline Multiple fracture, No. (\%) & $127(7.1)$ & $33(11.0)$ & 0.02 \\
\hline Hyponatremia, No. (\%) & $240(13.4)$ & $34(11.3)$ & 0.33 \\
\hline Hypoalbuminemia, No. (\%) & $542(30.3)$ & $117(39.0)$ & 0.003 \\
\hline $\begin{array}{l}\text { Glomerular filtration rate, median } \\
\text { (interquartile range), mL/min/1.73m² }\end{array}$ & $93.4(72.7,93.4)$ & $\begin{array}{l}84.4 \\
(68.3,84.4)\end{array}$ & $<0.001$
\end{tabular}

Intraoperative Clinical features

\begin{tabular}{llll} 
General anesthesia, No. (\%) & $1730(96.6)$ & $299(99.7)$ & 0.004 \\
$\begin{array}{l}\text { Anesthesia time, median (interquartile } \\
\text { range), hour }\end{array}$ & $5.0(3.5,5.0)$ & $5.1(2.9,5.1)$ & 0.54 \\
\hline Acute abdomen surgery, No. (\%) & $119(6.6)$ & $34(11.3)$ & 0.004 \\
\hline Aorta surgery, No. (\%) & $30(1.7)$ & $7(2.3)$ & 0.42 \\
\hline Brain surgery, No. (\%) & $391(21.8)$ & $59(19.7)$ & 0.40 \\
\hline Spine surgery, No. (\%) & $270(15.1)$ & $58(19.3)$ & 0.06 \\
\hline Thoracic surgery, No. (\%) & $53(3.0)$ & $13(4.3)$ & 0.21 \\
\hline Massive transfusion, No. (\%) & $57(3.2)$ & $33(11.0)$ & $<0.001$ \\
\hline Urine output $\leq$ 0.5ml/kg/hour, No. (\%) & $202(11.3)$ & $39(13.0)$ & 0.39 \\
\hline Continuous inotropes use, No. (\%) & $375(20.9)$ & $96(32.0)$ & $<0.001$ \\
\hline Red blood cells, median (interquartile & $24.3(12.1,24.3)$ & 32.9 & $<0.001$
\end{tabular}


range), \%

$(20.9,32.9)$

Red blood cells / hour, median

$4.6(2.0,4.6)$

$6.3(3.7,6.3)$

$<0.001$

(interquartile range), \%/hour

FFP, median (interquartile range), \%

$1.5(0.0,1.5)$

$9.5(0.0,9.5)$

$<0.001$

FFP/hour, median (interquartile range),

$0.1(0.0,0.1)$

$1.7(0.0,1.7)$

$<0.001$

$\% /$ hour

Total fluid, median (interquartile range), \%

113.7

$(87.9,113.7)$

119.7

0.04

Total fluid/hour, median (interquartile range), \%

$22.6(17.2,22.6)$

Estimated blood loss, median

(interquartile range), \%

$54.4(45.5,54.4)$

$(89.7,119.7)$

24.3

$(17.8,24.3)$

0.01

63.0

$(48.6,63.0)$

Postoperative clinical features

Patient controlled analgesia, No. (\%)

$1139(63.6)$

$181(60.3)$

0.27

Time-varying postoperative clinical features

\section{Period 1}

(No Postoperative pulmonary edema, $n=1866$; Postoperative pulmonary edema, $n=192$ )
Start time, median

(interquartile range),

$0.0(0.0,0.0)$

$0.0(0.0,0.0)$

1.000

hour

End time, median

(interquartile range),

$10.4(5.6,16.1)$

$0.8(0.3,6.2)$

$<0.001$

hour

Total Fluid, median (interquartile range),

$29.0(10.2,58.2)$

$2.4(0.0,24.5)$

$<0.001$ $\%$

Total Fluid/hour, median (interquartile range), \%/hour

Red blood cells, median (interquartile range), \%

$2.8(1.3,4.7)$

$1.5(0.0,4.4)$

$<0.001$

FFP, median

(interquartile range),

$0.0(0.0,0.0)$

$0.0(0.0,0.0)$

0.76

$0.0(0.0,0.0)$

$0.0(0.0,0.0)$

0.79

$\%$

Red blood cells/hour, median (interquartile range), \%/hour

FFP/hour, median (interquartile range),

$0.0(0.0,0.0)$

$0.0(0.0,0.0)$

0.88

$0.0(0.0,0.0)$

$0.0(0.0,0.0)$

0.34

$\% /$ hour

Increasing creatinine, $\quad 190(10.2)$

No. (\%)

$20(10.4)$

0.92 


\section{Period 2}

(No Postoperative pulmonary edema, $n=20$; Postoperative pulmonary edema, $n=1$ )

\section{Period 3}

(No Postoperative pulmonary edema, $n=11$; Postoperative pulmonary edema, $\mathrm{n}=0$ )
Start time, median (interquartile range),

$0.0(0.0,0.0)$

$0.0(0.0,0.0)$

1.000

hour

End time, median

(interquartile range),

$33.8(29.2,37.2) \quad 43.4$

$(43.4,43.4)$

0.48

hour

Total Fluid, median (interquartile range),

69.9 $\%$

$(42.7,119.4) \quad(25.6,25.6)$

0.38

Total Fluid/hour, median (interquartile

$2.5(1.5,3.4)$

$0.6(0.6,0.6)$

0.29 range), \%/hour

Red blood cells, median (interquartile $0.0(0.0,12.8)$ $5.0(5.0,5.0)$ 0.86 range), \%

FFP, median

(interquartile range),

$0.0(0.0,4.5)$

$0.0(0.0,0.0)$

0.67 $\%$

Red blood cells/hour, median (interquartile range), \%/hour

FFP/hour, median

$0.0(0.0,0.1)$

$0.0(0.0,0.0)$

0.67

(interquartile range),

$\% /$ hour

Increasing creatinine,

No. (\%)

$0.0(0.0,0.4)$

$0.1(0.1,0.1)$

0.86

Start time, median

(interquartile range),

hour

End time, median

(interquartile range),

$59.2(58.3,64.1)$

$2(10.0))$

$1(100.0)$

0.14 $0.0(0.0,0.0)$

hour

Total Fluid, median

74.8

(interquartile range),

$(22.0,140.3)$

$\%$

Total Fluid/hour, median (interquartile range), \%/hour

Red blood cells,

median (interquartile range), \%

FFP, median (interquartile range),

$1.2(0.4,2.3)$ $\%$ 


\begin{tabular}{|c|c|c|c|c|}
\hline & $\begin{array}{l}\text { Red blood cells/hour, } \\
\text { median (interquartile } \\
\text { range), \%/hour }\end{array}$ & \multicolumn{3}{|l|}{$0.0(0.0,0.0)$} \\
\hline & $\begin{array}{l}\text { FFP/hour, median } \\
\text { (interquartile range), } \\
\% / \text { hour }\end{array}$ & \multicolumn{3}{|l|}{$0.0(0.0,0.0)$} \\
\hline & $\begin{array}{l}\text { Increasing creatinine, } \\
\text { No. (\%) }\end{array}$ & \multicolumn{3}{|l|}{2 (18.2) } \\
\hline \multirow{9}{*}{$\begin{array}{l}\text { Period } 4 \\
\text { (No Postoperative } \\
\text { pulmonary edema, } n=1301 \text {; } \\
\text { Postoperative pulmonary } \\
\text { edema, } n=63 \text { ) }\end{array}$} & $\begin{array}{l}\text { Start time, median } \\
\text { (IQR), hour }\end{array}$ & $11.4(7.0,17.1)$ & $11.0(8.8,16.0)$ & 0.73 \\
\hline & $\begin{array}{l}\text { Start time, median } \\
\text { (interquartile range), } \\
\text { hour }\end{array}$ & $35.6(31.1,41.2)$ & $\begin{array}{l}34.2 \\
(30.9,37.5)\end{array}$ & 0.08 \\
\hline & $\begin{array}{l}\text { End time, median } \\
\text { (interquartile range), } \\
\text { hour }\end{array}$ & $\begin{array}{l}106.1 \\
(68.3,163.5)\end{array}$ & $\begin{array}{l}111.1 \\
(77.9,158.9)\end{array}$ & 0.29 \\
\hline & $\begin{array}{l}\text { Total Fluid, median } \\
\text { (interquartile range), } \\
\%\end{array}$ & $4.6(2.8,7.2)$ & $5.0(3.7,7.7)$ & 0.09 \\
\hline & $\begin{array}{l}\text { Total Fluid/hour, } \\
\text { median (interquartile } \\
\text { range), \%/hour }\end{array}$ & $0.0(0.0,10.3)$ & $9.5(0.0,25.9)$ & $<0.001$ \\
\hline & $\begin{array}{l}\text { Red blood cells, } \\
\text { median (interquartile } \\
\text { range), \% }\end{array}$ & $0.0(0.0,7.0)$ & $4.0(0.0,17.9)$ & $<0.001$ \\
\hline & $\begin{array}{l}\text { FFP, median } \\
\text { (interquartile range), } \\
\%\end{array}$ & $0.0(0.0,0.4)$ & $0.4(0.0,1.5)$ & $<0.001$ \\
\hline & $\begin{array}{l}\text { Red blood cells/hour, } \\
\text { median (interquartile } \\
\text { range), \%/hour }\end{array}$ & $0.0(0.0,0.3)$ & $0.2(0.0,0.8)$ & $<0.001$ \\
\hline & $\begin{array}{l}\text { FFP/hour, median } \\
\text { (interquartile range), } \\
\% / \text { hour }\end{array}$ & 198 (15.2) & $16(25.4)$ & 0.03 \\
\hline \multirow{4}{*}{$\begin{array}{l}\text { Period } 5 \\
\text { (No Postoperative } \\
\text { pulmonary edema, } n=81 \text {; } \\
\text { Postoperative pulmonary } \\
\text { edema, } n=2 \text { ) }\end{array}$} & $\begin{array}{l}\text { Start time, median } \\
\text { (interquartile range), } \\
\text { hour }\end{array}$ & $10.3(5.1,15.7)$ & $9.6(9.2,10.0)$ & 0.78 \\
\hline & $\begin{array}{l}\text { End time, median } \\
\text { (interquartile range), } \\
\text { hour }\end{array}$ & $58.5(53.8,64.6)$ & $\begin{array}{l}55.9 \\
(54.8,57.0)\end{array}$ & 0.49 \\
\hline & $\begin{array}{l}\text { Total Fluid, median } \\
\text { (interquartile range), } \\
\%\end{array}$ & $\begin{array}{l}89.2 \\
(60.9,160.2)\end{array}$ & $\begin{array}{l}124.3 \\
(111.2,137.5)\end{array}$ & 0.53 \\
\hline & Total Fluid/hour, & $2.0(1.4,3.2)$ & $2.7(2.4,2.9)$ & 0.43 \\
\hline
\end{tabular}


median (interquartile

range), \%/hour

Red blood cells,

$0.0(0.0,10.7)$

$2.6(1.3,4.0)$

0.81

median (interquartile

range), \%

FFP, median

$0.0(0.0,0.0)$

$1.8(0.9,2.7)$

0.53

(interquartile range), $\%$

Red blood cells/hour,

$0.0(0.0,0.2)$

$0.1(0.0,0.1)$

0.81 median (interquartile range), \%/hour

FFP/hour, median (interquartile range),

$0.0(0.0,0.0)$

$0.0(0.0,0.1)$

0.53

$\% /$ hour

\section{Period 6}

(No Postoperative pulmonary edema, $n=1008$; Postoperative pulmonary edema, $n=42$ )
Increasing creatinine, $\quad 1(1.2)$

No. (\%)

Start time, median

(interquartile range),

hour

End time, median

(interquartile range),

hour

Total Fluid, median

(interquartile range), $\%$

Total Fluid/hour, median (interquartile range), \%/hour

Red blood cells, median (interquartile range), \%

FFP, median (interquartile range),

$0.0(0.0,8.3)$

$(109.1,268.1)$

$7.7(4.6,11.5)$

$6.9(4.9,11.1)$

$>0.999$ $\%$

Red blood cells/hour, median (interquartile range), \%/hour

FFP/hour, median (interquartile range),

$0.0(0.0,13.9)$

$11.6(0.0,25.2)$ $\% /$ hour

Increasing creatinine, No. (\%)
$153(15.2)$

$0.0(0.0,0.6)$

$0.4(0.0,1.2)$

0.001
0.79

166.5

$(108.0,237.0)$

0.46

\section{2}

0.21 0.001

0.96

$(30.9,41.5)$ 
*Period 1: From end of anesthesia to 24 hours after anesthesia; Period 2: From end of anesthesia to 48 hours post anesthesia; Period 3: From end of anesthesia to 72 hours after anesthesia; Period 4: 24 hours after anesthesia to 48 hours after anesthesia; Period 5: 24 hours after anesthesia to 72 hours after anesthesia; Period 6: 48 hours after anesthesia to 72 hours after anesthesia

*Red blood cells, FFP, total fluid and estimated blood loss are expressed as ratio for average blood volume.

*FFP: fresh frozen plasma

Table 2. Demographic characteristics and clinical data in analysis of postoperative pulmonary edema with hypoxemia 
Variable

No

Postoperative

pulmonary

edema with

hypoxemia ( $\mathrm{n}=$

1499)

\section{Demographics}

\begin{tabular}{|llll|}
\hline Old Age, No. (\%) & $384(25.6)$ & $63(39.1)$ & $<0.001$ \\
\hline Men, No. (\%) & $730(48.7)$ & $88(54.7)$ & 0.15 \\
\hline Obesity, No. (\%) & $46(3.1)$ & $6(3.7)$ & 0.65
\end{tabular}

\section{Preoperative Clinical features}

\begin{tabular}{|c|c|c|c|}
\hline Emergency, №. (\%) & $516(34.4)$ & $89(55.3)$ & $<0.001$ \\
\hline $\begin{array}{l}\text { American Society of } \\
\text { Anesthesiologists physical status > } \\
2 \text {, No. (\%) }\end{array}$ & $698(46.6)$ & $117(72.7)$ & $<0.001$ \\
\hline Tobacco use, No. (\%) & $332(22.1)$ & $36(22.4)$ & 0.95 \\
\hline Brain trauma, No. (\%) & $183(12.2)$ & $24(14.9)$ & 0.33 \\
\hline Multiple fracture, No. (\%) & $106(7.1)$ & $19(11.8)$ & 0.03 \\
\hline Hyponatremia, No. (\%) & $195(13.0)$ & $21(13.0)$ & 0.99 \\
\hline Hypoalbuminemia, No. (\%) & $443(29.6)$ & $69(42.9)$ & 0.001 \\
\hline $\begin{array}{l}\text { Glomerular filtration rate, median } \\
\text { (interquartile range), } \\
\mathrm{mL} / \mathrm{min} / 1.73 \mathrm{~m}^{2}\end{array}$ & $\begin{array}{l}94.1(72.8- \\
122.9)\end{array}$ & $\begin{array}{l}83.7(65.4- \\
108.6)\end{array}$ & $<0.001$ \\
\hline \multicolumn{4}{|l|}{ linical features } \\
\hline General anesthesia, No. (\%) & $1445(96.4)$ & $160(99.4)$ & 0.05 \\
\hline $\begin{array}{l}\text { Anesthesia time, median } \\
\text { (interquartile range), hour }\end{array}$ & $5.0(3.5-6.9)$ & $4.7(2.8-7.2)$ & 0.58 \\
\hline Acute abdomen surgery, №. (\%) & $97(6.5)$ & $26(16.1)$ & $<0.001$ \\
\hline Aorta surgery, No. (\%) & $12(0.8)$ & $5(3.1)$ & 0.01 \\
\hline Brain surgery, No. (\%) & $319(21.3)$ & $35(21.7)$ & 0.89 \\
\hline Spine surgery, No. (\%) & $235(15.7)$ & $25(15.5)$ & 0.96 \\
\hline Thoracic surgery, No. (\%) & $41(2.7)$ & $6(3.7)$ & 0.47 \\
\hline Massive transfusion, No. (\%) & $35(2.3)$ & $25(15.5)$ & $<0.001$ \\
\hline $\begin{array}{l}\text { Urine output } \leq 0.5 \mathrm{ml} / \mathrm{kg} / \text { hour, No. } \\
(\%)\end{array}$ & $154(10.3)$ & $21(13.0)$ & 0.28 \\
\hline
\end{tabular}




\begin{tabular}{|c|c|c|c|c|}
\hline \multicolumn{2}{|c|}{ Continuous inotropes use, No. (\%) } & $279(18.6)$ & $62(38.5)$ & $<0.001$ \\
\hline \multicolumn{2}{|c|}{$\begin{array}{l}\text { Red blood cells, median } \\
\text { (interquartile range), \% }\end{array}$} & $23.7(11.8-37.2)$ & $34.6(21.1-61.0)$ & $<0.001$ \\
\hline \multicolumn{2}{|c|}{$\begin{array}{l}\text { Red blood cells /hour, median } \\
\text { (interquartile range), \%/hour }\end{array}$} & $4.6(1.9-8.0)$ & $6.9(3.8-16.7)$ & $<0.001$ \\
\hline \multicolumn{2}{|c|}{ FFP, median (interquartile range), \% } & $0.0(0.0-10.1)$ & $9.7(0.0-18.6)$ & $<0.001$ \\
\hline \multicolumn{2}{|c|}{$\begin{array}{l}\text { FFP/hour, median (interquartile } \\
\text { range), \%/hour }\end{array}$} & $0.0(0.0-2.1)$ & $1.9(0.0-5.4)$ & $<0.001$ \\
\hline \multicolumn{2}{|c|}{$\begin{array}{l}\text { Total fluid, median (interquartile } \\
\text { range), \% }\end{array}$} & $\begin{array}{l}113.6(87.8- \\
146.9)\end{array}$ & $\begin{array}{l}126.9(91.9- \\
178.0)\end{array}$ & 0.02 \\
\hline \multicolumn{2}{|c|}{$\begin{array}{l}\text { Total fluid/hour, median } \\
\text { (interquartile range), } \%\end{array}$} & $22.8(17.3-31.6)$ & $26.5(18.0-40.1)$ & 0.02 \\
\hline & $\begin{array}{l}\text { Estimated blood loss, median } \\
\text { (interquartile range), \% }\end{array}$ & $54.3(45.5-72.6)$ & $\begin{array}{l}66.7(51.0- \\
104.2)\end{array}$ & $<0.001$ \\
\hline \multicolumn{5}{|l|}{ Postoperative clinical features } \\
\hline & $\begin{array}{l}\text { Patient controlled analgesia, No. } \\
(\%)\end{array}$ & $979(65.3)$ & $83(51.6)$ & 0.001 \\
\hline \multicolumn{5}{|c|}{ Time-varying postoperative clinical features } \\
\hline \multirow{7}{*}{$\begin{array}{l}\text { Period } 1 \\
\text { (No Postoperative pulmonary } \\
\text { edema with hypoxemia, } \mathrm{n}= \\
1275 ; \text { Postoperative } \\
\text { pulmonary edema with } \\
\text { hypoxemia, } \mathrm{n}=72 \text { ) }\end{array}$} & $\begin{array}{l}\text { Start time, } \\
\text { median } \\
\text { (interquartile } \\
\text { range), hour }\end{array}$ & $0.0(0.0,0.0)$ & $0.0(0.0,0.0)$ & $>0.999$ \\
\hline & $\begin{array}{l}\text { End time, median } \\
\text { (interquartile } \\
\text { range), hour }\end{array}$ & $9.9(3.3,15.3)$ & $1.3(0.8,7.1)$ & $<0.001$ \\
\hline & $\begin{array}{l}\text { Total Fluid, } \\
\text { median } \\
\text { (interquartile } \\
\text { range), \% }\end{array}$ & $27.1(5.4,54.5)$ & $0.9(0.0,22.4)$ & $<0.001$ \\
\hline & $\begin{array}{l}\text { Total Fluid/hour, } \\
\text { median } \\
\text { (interquartile } \\
\text { range), \%/hour }\end{array}$ & $2.7(1.1,4.5)$ & $0.3(0.0,2.8)$ & $<0.001$ \\
\hline & $\begin{array}{l}\text { Red blood cells, } \\
\text { median } \\
\text { (interquartile } \\
\text { range), \% }\end{array}$ & $0.0(0.0,0.0)$ & $0.0(0.0,7.1)$ & 0.001 \\
\hline & $\begin{array}{l}\text { FFP, median } \\
\text { (interquartile } \\
\text { range), } \%\end{array}$ & $0.0(0.0,0.0)$ & $0.0(0.0,5.3)$ & 0.004 \\
\hline & Red blood & $0.0(0.0,0.0)$ & $0.0(0.0,1.7)$ & $<0.001$ \\
\hline
\end{tabular}


cells/hour,

median

(interquartile

range), \%/hour

\begin{tabular}{llll}
$\begin{array}{l}\text { FFP/hour, median } \\
\text { (interquartile } \\
\text { range), \%/hour }\end{array}$ & $0.0(0.0,0.0)$ & $0.0(0.0,0.6)$ & 0.002 \\
\hline $\begin{array}{l}\text { Increasing } \\
\text { creatinine, No. }\end{array}$ & $99(7.8)$ & $11(15.3)$ & 0.02 \\
\hline
\end{tabular}

\section{Period 2}

(No Postoperative pulmonary edema with hypoxemia, $\mathrm{n}=$ 148; Postoperative pulmonary edema with hypoxemia, $\mathrm{n}=$ 42)

\begin{tabular}{llll}
$\begin{array}{l}\text { Start time, } \\
\text { median } \\
\text { (interquartile } \\
\text { range), hour }\end{array}$ & $0.0(0.0,0.0)$ & $0.0(0.0,0.0)$ & $>0.999$ \\
$\begin{array}{l}\text { End time, median } \\
\text { (interquartile }\end{array}$ & $37.2(31.3,41.6)$ & $\begin{array}{l}35.3(30.0, \\
39.6)\end{array}$ & 0.12 \\
range), hour & & & \\
\hline $\begin{array}{l}\text { Total Fluid, } \\
\text { median } \\
\text { (interquartile }\end{array}$ & $\begin{array}{l}102.3(70.7, \\
\text { range), \% }\end{array}$ & $\begin{array}{l}102.9(54.0, \\
145.5)\end{array}$ & 0.76 \\
\hline
\end{tabular}

Total Fluid/hour, $\quad 2.9(1.9,4.1) \quad 2.8(1.6,4.4) \quad 0.93$ median

(interquartile range), \%/hour

$\begin{array}{llll}\text { Red blood cells, } \quad 0.0(0.0,7.4) & 0.0(0.0,21.2) \quad 0.05\end{array}$ median (interquartile range), \%

\begin{tabular}{llll|}
$\begin{array}{l}\text { FFP, median } \\
\text { (interquartile } \\
\text { range), \% }\end{array}$ & $0.0(0.0,0.0)$ & $7.9(0.0,21.6)$ & $<0.001$ \\
$\begin{array}{l}\text { Red blood } \\
\text { cells/hour, } \\
\text { median } \\
\text { (interquartile } \\
\text { range), \%/hour }\end{array}$ & $0.0(0.0,0.2)$ & $0.0(0.0,0.6)$ & 0.04 \\
$\begin{array}{l}\text { FFP/hour, median } \\
\text { (interquartile } \\
\text { range), \%/hour }\end{array}$ & $0.0(0.0,0.0)$ & $0.3(0.0,0.6)$ & $<0.001$ \\
$\begin{array}{l}\text { Increasing } \\
\text { creatinine, No. } \\
\text { (\%) }\end{array}$ & $17(11.5)$ & $19(45.2)$ & $<0.001$ \\
$\begin{array}{l}\text { Start time, } \\
\text { median } \\
\text { (interquartile } \\
\text { range), hour }\end{array}$ & $0.0(0.0,0.0)$ & $0.0(0.0,0.0)$ & $>0.999$ \\
\hline
\end{tabular}


86; Postoperative pulmonary edema with hypoxemia $\mathrm{n}=$ 21)
End time, median (interquartile range), hour

Total Fluid, median (interquartile range), \%

Total Fluid/h, median

(interquartile range), \%/hour

Red blood cells, median

(interquartile range), \%

FFP, median (interquartile $0.1(0.0,0.3)$ $4.3(0.0,21.7)$ 132.7 (75.9, 222.2) $198.8(118.1$ 279.2)

$57.2(54.5$, 61.2)

$59.1(55.3,64.8)$

range), \%

Red blood

cells/hour, median (interquartile range), \%/hour

FFP/hour, median $\quad 0.0(0.0,8.5)$ (interquartile range), \%/hour

Increasing creatinine, No.

(\%)

\section{Period 4}

(No Postoperative pulmonary edema with hypoxemia, $\mathrm{n}=$ 583; Postoperative pulmonary edema with hypoxemia, $\mathrm{n}=0$ )

$2.2(1.3,3.8)$

$3.4(2.1,5.0)$
Start time,

median

(interquartile range), hour

End time, median $36.9(31.9,40.8)$

(interquartile range), hour

Total Fluid, median (interquartile range), \%

Total Fluid/hour, $\quad 0.0(0.0,20.7)$ median (interquartile range), \%/hour

Red blood cells, $\quad 4.6(3.0,7.4)$ median
$116.0(78.3$

178.2)
$38.5(10.0, \quad 0.04$

$82.3)$

0.01

$0.0(0.0,14.0) \quad 11.0(0.0,44.0) \quad 0.01$

$0.6(0.2,1.4) \quad 0.01$ 0.01 0.01 $8.3(0.0,40.0) \quad 0.01$ 
(interquartile range), \%

$\begin{array}{ll}\begin{array}{l}\text { FFP, median } \\ \text { (interquartile } \\ \text { range), \% }\end{array} & 0.0(0.0,0.8) \\ \begin{array}{l}\text { Red blood } \\ \text { cells/hour, }\end{array} & 0.0(0.0,10.2) \\ \text { median } \\ \text { (interquartile } \\ \text { range), \%/hour }\end{array}$
FFP/hour, median $\quad 0.0(0.0,7.9)$
(interquartile range), \%/hour

Increasing
creatinine, No.
$(\%)$

\section{Period 5}

(No Postoperative pulmonary edema with hypoxemia, $\mathrm{n}=$ 148; Postoperative pulmonary edema with hypoxemia, $\mathrm{n}=$ 12)

\begin{tabular}{|c|c|c|c|}
\hline $\begin{array}{l}\text { Start time, } \\
\text { median } \\
\text { (interquartile } \\
\text { range), hour }\end{array}$ & $10.5(5.5,15.5)$ & $9.4(7.1,16.9)$ & 0.66 \\
\hline $\begin{array}{l}\text { End time, median } \\
\text { (interquartile } \\
\text { range), hour }\end{array}$ & $60.0(55.6,64.3)$ & $\begin{array}{l}59.5(55.1 \\
63.2)\end{array}$ & 0.77 \\
\hline $\begin{array}{l}\text { Total Fluid, } \\
\text { median } \\
\text { (interquartile } \\
\text { range), \% }\end{array}$ & $\begin{array}{l}137.2(79.0 \\
211.5)\end{array}$ & $\begin{array}{l}227.4(186.0 \\
284.8)\end{array}$ & 0.003 \\
\hline $\begin{array}{l}\text { Total Fluid/hour, } \\
\text { median } \\
\text { (interquartile } \\
\text { range), \%/hour }\end{array}$ & $0.0(0.0,16.9)$ & $22.3(0.0,41.4)$ & 0.003 \\
\hline $\begin{array}{l}\text { Red blood cells, } \\
\text { median } \\
\text { (interquartile } \\
\text { range), \% }\end{array}$ & $2.8(1.7,4.4)$ & $5.0(3.5,5.9)$ & 0.39 \\
\hline $\begin{array}{l}\text { FFP, median } \\
\text { (interquartile } \\
\text { range), \% }\end{array}$ & $0.0(0.0,0.4)$ & $0.5(0.0,0.9)$ & 0.03 \\
\hline $\begin{array}{l}\text { Red blood } \\
\text { cells/hour, } \\
\text { median } \\
\text { (interquartile } \\
\text { range), \%/hour }\end{array}$ & $0.0(0.0,13.9)$ & $5.9(0.0,14.0)$ & 0.32 \\
\hline $\begin{array}{l}\text { FFP/hour, median } \\
\text { (interquartile } \\
\text { range), \%/hour }\end{array}$ & $0.0(0.0,5.2)$ & $6.8(0.0,24.2)$ & 0.03 \\
\hline
\end{tabular}


Increasing creatinine, No.

(\%)

\section{Period 6}

(No Postoperative pulmonary edema with hypoxemia, $\mathrm{n}=$ 384; Postoperative pulmonary edema with hypoxemia, $\mathrm{n}=$ 14) median (interquartile range), hour (interquartile
Start time, $37.3(32.2,41.3)$

End time, median range), hour

Total Fluid, median (interquartile range), \%

Total Fluid/hour, median (interquartile range), \%/hour

\begin{tabular}{|c|c|c|c|}
\hline $\begin{array}{l}\text { Red blood cells, } \\
\text { median } \\
\text { (interquartile } \\
\text { range), \% }\end{array}$ & $8.6(5.3,12.8)$ & $7.1(5.5,9.0)$ & $>0.999$ \\
\hline $\begin{array}{l}\text { FFP, median } \\
\text { (interquartile } \\
\text { range), \% }\end{array}$ & $0.3(0.0,1.3)$ & $1.4(0.5,2.8)$ & 0.27 \\
\hline $\begin{array}{l}\text { Red blood } \\
\text { cells/hour, } \\
\text { median } \\
\text { (interquartile } \\
\text { range), \%/hour }\end{array}$ & $0.0(0.0,14.0)$ & $\begin{array}{l}18.4(14.7 \\
37.0)\end{array}$ & $>0.999$ \\
\hline $\begin{array}{l}\text { FFP/hour, median } \\
\text { (interquartile } \\
\text { range), \%/hour }\end{array}$ & $0.0(0.0,13.3)$ & $2.6(0.0,22.9)$ & 0.30 \\
\hline $\begin{array}{l}\text { Increasing } \\
\text { creatinine, No. } \\
(\%)\end{array}$ & $47(12.2)$ & $4(28.6)$ & 0.07 \\
\hline
\end{tabular}

*Period 1: From end of anesthesia to 24 hours after anesthesia; Period 2: From end of anesthesia to 48 hours post anesthesia; Period 3: From end of anesthesia to 72 hours after anesthesia; Period 4: 24 hours after anesthesia to 48 hours after anesthesia; Period 5: 24 hours after anesthesia to 72 hours after anesthesia; Period 6: 48 hours after anesthesia to 72 hours after anesthesia

*Red blood cells, FFP, total fluid and estimated blood loss are expressed as ratio for average blood volume. 
*FFP: fresh frozen plasma

Table 3. Adjusted hazard ratio of all variables for postoperative pulmonary edema occurrence

\begin{tabular}{|c|c|c|c|c|}
\hline & $\begin{array}{l}\text { Hazard } \\
\text { ratio }\end{array}$ & $\begin{array}{l}\text { Lower } 95 \% \\
\text { confidence interval }\end{array}$ & $\begin{array}{l}\text { upper } 95 \% \\
\text { confidence interval }\end{array}$ & $\mathrm{p}$ \\
\hline Old age & 1.13 & 0.96 & 1.32 & 0.13 \\
\hline Male & 1.04 & 0.90 & 1.21 & 0.56 \\
\hline Obesity & 0.95 & 0.65 & 1.37 & 0.78 \\
\hline Emergency & 1.09 & 0.93 & 1.27 & 0.30 \\
\hline $\begin{array}{l}\text { American Society of } \\
\text { Anesthesiologists physical status }>2\end{array}$ & 1.09 & 0.94 & 1.27 & 0.24 \\
\hline Anesthesia time & 1.00 & 0.98 & 1.03 & 0.77 \\
\hline Anesthesia & 1.43 & 0.91 & 2.24 & 0.12 \\
\hline Patient controlled analgesia & 1.01 & 0.87 & 1.19 & 0.85 \\
\hline Tabaco use & 0.96 & 0.81 & 1.14 & 0.65 \\
\hline Brain Trauma & 0.96 & 0.77 & 1.19 & 0.73 \\
\hline Multiple fracture & 1.09 & 0.84 & 1.41 & 0.52 \\
\hline Acute abdomen surgery & 1.01 & 0.77 & 1.31 & 0.96 \\
\hline Aorta surgery & 0.85 & 0.52 & 1.38 & 0.50 \\
\hline Brain surgery & 0.93 & 0.77 & 1.12 & 0.42 \\
\hline Spine surgery & 1.23 & 1.00 & 1.52 & 0.05 \\
\hline Thoracic surgery & 1.05 & 0.72 & 1.52 & 0.80 \\
\hline Massive transfusion & 1.24 & 0.87 & 1.77 & 0.24 \\
\hline Estimated blood loss & 1.00 & 1.00 & 1.00 & 0.99 \\
\hline Intraoperative inotropes & 1.04 & 0.88 & 1.24 & 0.62 \\
\hline Preoperative hyponatremia & 0.94 & 0.76 & 1.16 & 0.57 \\
\hline Preoperative. hypoalbuminemia & 1.10 & 0.94 & 1.28 & 0.25 \\
\hline
\end{tabular}

FFP: fresh frozen plasma

Table 4. Adjusted hazard ratio of all variables for postoperative pulmonary edema with hypoxemia occurrence 


\begin{tabular}{|c|c|c|c|c|}
\hline & $\begin{array}{l}\text { Hazard } \\
\text { ratio }\end{array}$ & $\begin{array}{l}\text { Lower } 95 \% \\
\text { confidence interval }\end{array}$ & $\begin{array}{l}\text { upper } 95 \% \\
\text { confidence interval }\end{array}$ & $\mathrm{p}$ \\
\hline Old age & 1.27 & 1.03 & 1.58 & 0.03 \\
\hline Male & 1.02 & 0.84 & 1.23 & 0.86 \\
\hline Obesity & 1.10 & 0.62 & 1.93 & 0.74 \\
\hline Emergency & 1.14 & 0.93 & 1.40 & 0.21 \\
\hline $\begin{array}{l}\text { American Society of } \\
\text { Anesthesiologists physical status }>2\end{array}$ & 1.24 & 1.02 & 1.50 & 0.03 \\
\hline Anesthesia time & 1.01 & 0.97 & 1.04 & 0.73 \\
\hline Anesthesia & 1.37 & 0.78 & 2.43 & 0.27 \\
\hline Patient controlled analgesia & 0.92 & 0.75 & 1.13 & 0.41 \\
\hline Tabaco use & 1.01 & 0.80 & 1.26 & 0.96 \\
\hline Brain Trauma & 0.96 & 0.73 & 1.26 & 0.75 \\
\hline Multiple fracture & 1.08 & 0.76 & 1.53 & 0.67 \\
\hline Acute abdomen surgery & 1.10 & 0.78 & 1.55 & 0.58 \\
\hline Aorta surgery & 1.49 & 0.66 & 3.41 & 0.34 \\
\hline Brain surgery & 0.95 & 0.75 & 1.20 & 0.67 \\
\hline Spine surgery & 1.12 & 0.85 & 1.48 & 0.42 \\
\hline Thoracic surgery & 1.01 & 0.58 & 1.74 & 0.98 \\
\hline Massive transfusion & 1.59 & 0.97 & 2.62 & 0.07 \\
\hline Estimated blood loss & 1.00 & 1.00 & 1.00 & 0.95 \\
\hline Intraoperative inotropes & 1.12 & 0.89 & 1.41 & 0.35 \\
\hline Preoperative hyponatremia & 1.04 & 0.79 & 1.38 & 0.77 \\
\hline Preoperative. hypoalbuminemia & 1.17 & 0.95 & 1.43 & 0.13 \\
\hline
\end{tabular}

FFP: fresh frozen plasma

\section{Figures}




\title{
Hazard ratio (95\% confidence interval)
}

Unadjusted hazard ratio [ $95 \%$ confidence interval] Preoperative glomerular filtration rate (1.00 [1.00-1.00]) Intraoperative red blood cells (1.01 [1.00-1.01]) Intraoperative FFP (1.01 [1.01-1.02])

Intraoperative red blood cells/hour (1.02 [1.01-1.03]) Intraoperative FFP/hour (1.07 [1.05-1.09]) Intraoperative total fluid (1.00 [1.00-1.00]) Intraoperative total fluid/hour (1.00[1.00-1.01]) Intraoperative urine output $\leq 0.5 \mathrm{ml} / \mathrm{kg} /$ hour (1.06 [0.85-1.32])

Postoperative total fluid (1.00 [1.00-1.00]) Postoperative total fluid/hour (1.01 [1.00-1.01]) Postoperative red blood cells (1.01 [1.00-1.01]) Postoperative FFP (1.00 [1.00-1.01]) Postoperative red blood cells/hour (1.05 [1.03-1.06]) Postoperative FFP/hour (1.04 [1.01-1.08])

Postoperative creatinine increasing (1.13 [0.92-1.39])

Adjusted hazard ratio [ $95 \%$ confidence interval] Preoperative glomerular filtration rate (1.00 [1.00-1.00]) Intraoperative red blood cells (1.00 [1.00-1.00]) Intraoperative FFP $(1.00[1.00-1.01])$ Intraoperative red blood cells/hour (1.01 [1.00-1.02]) Intraoperative FFP/hour (1.03 [1.00-1.06]) Intraoperative total fluid (1.00 [1.00-1.00]) Intraoperative total fluid/hour (1.00 [1.00-1.00]) Intraoperative urine output $\leq 0.5 \mathrm{ml} / \mathrm{kg} /$ hour $(1.01[0.81-1.26])$ Postoperative total fluid (1.00 [1.00-1.00]) Postoperative total fluid/hour (1.01 [1.00-1.01]) Postoperative red blood cells (1.00 [1.00-1.01]) Postoperative FFP (1.00 [0.99-1.00])

Postoperative red blood cells/hour (1.03 [1.01-1.05]) Postoperative FFP/hour (1.02 [0.99-1.06])

Postoperative creatinine increasing (1.02 [0.83-1.26])

\author{
- Lower $95 \%$ confidence interval = Upper $95 \%$ confidence interval
}

\section{Figure 1}

Unadjusted and adjusted hazard ratio for postoperative pulmonary edema occurrence FFP: fresh frozen plasma 


\title{
Hazard ratio (95\% confidence interval)
}

Unadjusted hazard ratio [ $95 \%$ confidence interval] Preoperative glomerular filtration rate (1.00 [1.00-1.00]) Intraoperative red blood cells (1.01 [1.00-1.01]) Intraoperative FFP (1.01 [1.01-1.02])

Intraoperative red blood cells/hour (1.02 [1.01-1.03]) Intraoperative FFP/hour (1.07 [1.05-1.09]) Intraoperative total fluid (1.00 [1.00-1.00]) Intraoperative total fluid/hour (1.00[1.00-1.01]) Intraoperative urine output $\leq 0.5 \mathrm{ml} / \mathrm{kg} /$ hour (1.06 [0.85-1.32])

Postoperative total fluid (1.00 [1.00-1.00]) Postoperative total fluid/hour (1.01 [1.00-1.01]) Postoperative red blood cells (1.01 [1.00-1.01]) Postoperative FFP (1.00 [1.00-1.01]) Postoperative red blood cells/hour (1.05 [1.03-1.06]) Postoperative FFP/hour (1.04 [1.01-1.08])

Postoperative creatinine increasing (1.13 [0.92-1.39])

Adjusted hazard ratio [ $95 \%$ confidence interval] Preoperative glomerular filtration rate (1.00 [1.00-1.00]) Intraoperative red blood cells (1.00 [1.00-1.00]) Intraoperative FFP $(1.00[1.00-1.01])$ Intraoperative red blood cells/hour (1.01 [1.00-1.02]) Intraoperative FFP/hour (1.03 [1.00-1.06]) Intraoperative total fluid (1.00 [1.00-1.00]) Intraoperative total fluid/hour (1.00 [1.00-1.00]) Intraoperative urine output $\leq 0.5 \mathrm{ml} / \mathrm{kg} /$ hour $(1.01[0.81-1.26])$ Postoperative total fluid (1.00 [1.00-1.00]) Postoperative total fluid/hour (1.01 [1.00-1.01]) Postoperative red blood cells (1.00 [1.00-1.01]) Postoperative FFP (1.00 [0.99-1.00])

Postoperative red blood cells/hour (1.03 [1.01-1.05]) Postoperative FFP/hour (1.02 [0.99-1.06])

Postoperative creatinine increasing (1.02 [0.83-1.26])

\author{
- Lower $95 \%$ confidence interval = Upper $95 \%$ confidence interval
}

\section{Figure 1}

Unadjusted and adjusted hazard ratio for postoperative pulmonary edema occurrence FFP: fresh frozen plasma 


\title{
Hazard ratio (95\% confidence interval)
}

Unadjusted hazard ratio [ $95 \%$ confidence interval] Preoperative glomerular filtration rate (1.00 [1.00-1.00]) Intraoperative red blood cells (1.01 [1.00-1.01]) Intraoperative FFP (1.01 [1.01-1.02])

Intraoperative red blood cells/hour (1.02 [1.01-1.03]) Intraoperative FFP/hour (1.07 [1.05-1.09]) Intraoperative total fluid (1.00 [1.00-1.00]) Intraoperative total fluid/hour (1.00[1.00-1.01]) Intraoperative urine output $\leq 0.5 \mathrm{ml} / \mathrm{kg} /$ hour (1.06 [0.85-1.32])

Postoperative total fluid (1.00 [1.00-1.00]) Postoperative total fluid/hour (1.01 [1.00-1.01]) Postoperative red blood cells (1.01 [1.00-1.01]) Postoperative FFP (1.00 [1.00-1.01]) Postoperative red blood cells/hour (1.05 [1.03-1.06]) Postoperative FFP/hour (1.04 [1.01-1.08])

Postoperative creatinine increasing (1.13 [0.92-1.39])

Adjusted hazard ratio [ $95 \%$ confidence interval] Preoperative glomerular filtration rate (1.00 [1.00-1.00]) Intraoperative red blood cells (1.00 [1.00-1.00]) Intraoperative FFP $(1.00[1.00-1.01])$ Intraoperative red blood cells/hour (1.01 [1.00-1.02]) Intraoperative FFP/hour (1.03 [1.00-1.06]) Intraoperative total fluid (1.00 [1.00-1.00]) Intraoperative total fluid/hour (1.00 [1.00-1.00]) Intraoperative urine output $\leq 0.5 \mathrm{ml} / \mathrm{kg} /$ hour $(1.01[0.81-1.26])$ Postoperative total fluid (1.00 [1.00-1.00]) Postoperative total fluid/hour (1.01 [1.00-1.01]) Postoperative red blood cells (1.00 [1.00-1.01]) Postoperative FFP (1.00 [0.99-1.00])

Postoperative red blood cells/hour (1.03 [1.01-1.05]) Postoperative FFP/hour (1.02 [0.99-1.06])

Postoperative creatinine increasing (1.02 [0.83-1.26])

\author{
- Lower $95 \%$ confidence interval = Upper $95 \%$ confidence interval
}

\section{Figure 1}

Unadjusted and adjusted hazard ratio for postoperative pulmonary edema occurrence FFP: fresh frozen plasma 


\section{Hazard ratio (95\% confidence interval)}

Unadjusted hazard ratio [95\% confidence interval] Preoperative glomerular filtration rate (1.00 [1.00-1.00]) Intraoperative red blood cells (1.01, [1.00-1.01]) Intraoperative FFP (1.01 [1.01-1.02]) Intraoperative red blood cells/hour (1.03 [1.02-1.03]) Intraoperative FFP/hour (1.10 [1.07-1.13]) Intraoperative Total fluid (1.00, [1.00-1.00]) Intraoperative Total fluid/hour (1.00 [1.00-1.01]) Intraoperative urine output $\leq 0.5 \mathrm{ml} / \mathrm{kg} / \mathrm{hour}(1.10[0.81-1.50])$ Postoperative total fluid (1.00 [1.00-1.00]) Postoperative total fluid/hour (0.99 [0.98-1.01]) Postoperative red blood cells (1.01 [1.01-1.02]) Postoperative FFP (1.01 [1.00-1.01]) Postoperative red blood cells/hour (1.09 [1.07-1.11]) Postoperative FFP/hour (1.17 [1.12-1.22]) Postoperative creatinine increasing $(1.75[1.33-2.30])$

Adjusted hazard ratio [95\% confidence interval] Preoperative glomerular filtration rate $(1.00$ [1.00-1.00]) Intraoperative red blood cells (1.00 [1.00-1.00]) Intraoperative FFP (1.00 [0.99-1.01]) Intraoperative red blood cells/hour (1.01 [0.99-1.02]) Intraoperative FFP/hour (1.03 [1.00-1.07])

Intraoperative Total fluid (1.00 [1.00-1.00])

Intraoperative Total fluid/hour (1.00 [1.00-1.00]) Intraoperative urine output $\leq 0.5 \mathrm{ml} / \mathrm{kg} /$ hour $(0.99[0.73-1.34])$

Postoperative total fluid (1.00 [1.00-1.00]) Postoperative total fluid/hour (0.99, [0.98-1.01]) Postoperative red blood cells $(1.00,[1.00-1.01])$ Postoperative FFP $(1.00,[0.99-1.01])$ Postoperative red blood cells/hour (1.04 [1.01-1.07]) Postoperative FFP/hour (1.06 [0.99-1.13]) Postoperative creatinine increasing (1.43 [1.08-1.89])

\section{Figure 2}

Unadjusted and adjusted hazard ratio for occurrence of postoperative pulmonary edema with hypoxemia FFP: fresh frozen plasma 


\section{Hazard ratio (95\% confidence interval)}

Unadjusted hazard ratio [95\% confidence interval] Preoperative glomerular filtration rate (1.00 [1.00-1.00]) Intraoperative red blood cells (1.01, [1.00-1.01]) Intraoperative FFP (1.01 [1.01-1.02]) Intraoperative red blood cells/hour (1.03 [1.02-1.03]) Intraoperative FFP/hour (1.10 [1.07-1.13]) Intraoperative Total fluid (1.00, [1.00-1.00]) Intraoperative Total fluid/hour (1.00 [1.00-1.01]) Intraoperative urine output $\leq 0.5 \mathrm{ml} / \mathrm{kg} / \mathrm{hour}(1.10[0.81-1.50])$ Postoperative total fluid (1.00 [1.00-1.00]) Postoperative total fluid/hour (0.99 [0.98-1.01]) Postoperative red blood cells (1.01 [1.01-1.02]) Postoperative FFP (1.01 [1.00-1.01]) Postoperative red blood cells/hour (1.09 [1.07-1.11]) Postoperative FFP/hour (1.17 [1.12-1.22]) Postoperative creatinine increasing $(1.75[1.33-2.30])$

Adjusted hazard ratio [95\% confidence interval] Preoperative glomerular filtration rate $(1.00$ [1.00-1.00]) Intraoperative red blood cells (1.00 [1.00-1.00]) Intraoperative FFP (1.00 [0.99-1.01]) Intraoperative red blood cells/hour (1.01 [0.99-1.02]) Intraoperative FFP/hour (1.03 [1.00-1.07])

Intraoperative Total fluid (1.00 [1.00-1.00])

Intraoperative Total fluid/hour (1.00 [1.00-1.00]) Intraoperative urine output $\leq 0.5 \mathrm{ml} / \mathrm{kg} /$ hour $(0.99[0.73-1.34])$

Postoperative total fluid (1.00 [1.00-1.00]) Postoperative total fluid/hour (0.99, [0.98-1.01]) Postoperative red blood cells $(1.00,[1.00-1.01])$ Postoperative FFP $(1.00,[0.99-1.01])$ Postoperative red blood cells/hour (1.04 [1.01-1.07]) Postoperative FFP/hour (1.06 [0.99-1.13]) Postoperative creatinine increasing (1.43 [1.08-1.89])

\section{Figure 2}

Unadjusted and adjusted hazard ratio for occurrence of postoperative pulmonary edema with hypoxemia FFP: fresh frozen plasma 


\section{Hazard ratio (95\% confidence interval)}

Unadjusted hazard ratio [95\% confidence interval] Preoperative glomerular filtration rate (1.00 [1.00-1.00]) Intraoperative red blood cells (1.01, [1.00-1.01]) Intraoperative FFP (1.01 [1.01-1.02]) Intraoperative red blood cells/hour (1.03 [1.02-1.03]) Intraoperative FFP/hour (1.10 [1.07-1.13]) Intraoperative Total fluid (1.00, [1.00-1.00]) Intraoperative Total fluid/hour (1.00 [1.00-1.01]) Intraoperative urine output $\leq 0.5 \mathrm{ml} / \mathrm{kg} / \mathrm{hour}(1.10[0.81-1.50])$ Postoperative total fluid (1.00 [1.00-1.00]) Postoperative total fluid/hour (0.99 [0.98-1.01]) Postoperative red blood cells (1.01 [1.01-1.02]) Postoperative FFP (1.01 [1.00-1.01]) Postoperative red blood cells/hour (1.09[1.07-1.11]) Postoperative FFP/hour (1.17 [1.12-1.22]) Postoperative creatinine increasing $(1.75[1.33-2.30])$

Adjusted hazard ratio [95\% confidence interval] Preoperative glomerular filtration rate (1.00 [1.00-1.00]) Intraoperative red blood cells (1.00 [1.00-1.00]) Intraoperative FFP (1.00 [0.99-1.01])

Intraoperative red blood cells/hour (1.01 [0.99-1.02]) Intraoperative FFP/hour (1.03 [1.00-1.07])

Intraoperative Total fluid (1.00 [1.00-1.00])

Intraoperative Total fluid/hour (1.00 [1.00-1.00]) Intraoperative urine output $\leq 0.5 \mathrm{ml} / \mathrm{kg} /$ hour $(0.99[0.73-1.34])$

Postoperative total fluid $(1.00[1.00-1.00])$ Postoperative total fluid/hour (0.99, [0.98-1.01]) Postoperative red blood cells $(1.00,[1.00-1.01])$ Postoperative FFP $(1.00,[0.99-1.01])$ Postoperative red blood cells/hour (1.04 [1.01-1.07]) Postoperative FFP/hour (1.06 [0.99-1.13]) Postoperative creatinine increasing (1.43 [1.08-1.89])

\section{Figure 2}

Unadjusted and adjusted hazard ratio for occurrence of postoperative pulmonary edema with hypoxemia FFP: fresh frozen plasma 